\title{
THE SURVEY OF THE LEVEL OF INTERACTIVE WHITEBOARDS USE IN INQUIRY BASED LEARNING IN BIOLOGY AT BASIC SCHOOLS
}

\author{
Renata RYPLOVÁ, Jihočeská univerzita v Českých Budějovicích, \\ Česká republika
}

Přijato: 27. 6. 2017 / Akceptováno: 30. 8. 2017

Typ článku: Výzkumná studie

DOI: $10.5507 /$ jtie.2017.018

Abstract: This contribution brings the results of the survey focused on the frequency and way of use of interactive whiteboards in inquiry based science education among the science teachers at Czech basic schools. These results indicate, that interactive whiteboards are used in inquiry based science education quite seldom and it's potential for individual steps of inquiry approach is not yet entirely used. The mentioned problems in use of interactive whiteboards in inquiry based science education at Czech basic schools are analysed.

Key words: inquiry based education, interactive white board, biology

\section{SONDA MÍRY VYUŽITÍ INTERAKTIVNÍ TABULE V BADATELSKY ORIENTOVANÉM VYUČOVÁNÍ V PŘÍRODOPISU NA ZÁKLADNÍCH ŠKOLÁCH}

Abstrakt: Sonda, jejiž výsledky přináši tento přispěvek, byla provedena s cílem zmapovat míru využíváni interaktivni tabule vbadatelsky orientovaném vyučování mezi učiteli př́rodopisu českých základních škol. Výsledky sondy naznačuji, že potenciál interaktivní tabule pro jednotlivé kroky badatelské výuky neni v současné době dostatečně využit. Jsou analyzovány zjištěné problémy, s nimiž se potýkají učitelé prrirodopisu, kteři se snaži v praxi moderni didaktický prístup badatelské výuky s využitím interaktivni tabule zkombinovat.

Klíčová slova: badatelsky orientované vyučování, interaktivní tabule, př́rodopis

\footnotetext{
*Autor pro korespondenci: ryplova@pf.jcu.cz
} 


\section{1 Úvod}

Badatelsky orientovaná výuka (BOV) je moderní didaktický trend uplatňovaný ve výuce prrírodopisu a dalších př́rodovědných předmětů na českých školách v průběhu posledních let s cílem zvýšit mj. atraktivitu prrírodovědného vzdělání pro mladou generaci (Papáček, 2010; Dostál, 2013). Během badatelské výuky žák dospívá k novým poznatkům cestou vlastního poznání a vyvozování závěrů pod vedením učitele, tedy způsobem obdobným badatelskému principu vědců (NRC, 2012). Podle zahraničních studií, implementaci BOV výrazně usnadňuje použití moderních didaktických technologií, např. využití potenciálu interaktivních tabulí (IT), (Lee et al., 2010). IT jsou na českých základních školách široce dostupné zejména díky projektům implementace ICT do vzdělávání v minulých letech. Doposud však neexistují informace o tom, zda a jakým způsobem čeští učitelé IT využívají i v rámci moderního principu BOV a jaká je reflexe praktického využití interaktivních tabulí ve spojení s badatelským př́stupem k výuce. $\mathrm{Z}$ tohoto důvodu byla provedena sonda, jejíž výsledky přináší následující př́spěvek. Hlavním cílem této studie bylo zjistit, zda a v jakém rozsahu využívají učitelé přírodopisu IT pro badatelskou výuku, v čem vidí v praxi př́nosy a výhody IT pro BOV a naopak, na jaké problémy a nedostatky narážejí. Vedlejším cílem byl i monitoring způsobů využití IT ve výuce př́rodopisu na ZŠ mimo BOV.

\section{Badatelsky orientovaná výuka v přírodopisu na základních školách}

Na základě pozitivních zahraničních zkušeností (Rochard et al., 2007; NRC, 1996) dochází v současné době i na českých základních školách kimplementaci tzv. badatelského prŕístupu do výuky př́rodopisu. Cílem těchto snah je zatraktivnit a lépe zpřístupnit výuku přírodovědných předmětů současné mladé generaci. Jedná se o aktivní výukový proces, během něhož žák dospívá k poznání cestou bádání, tedy procesem řešení výzkumných otázek na základě analýzy získaných dat (Bell, 2005). Badatelská výuka zahrnuje řadu aktivit, během nichž žák samostatně, pouze směřován učitelem, dochází k tzv. vědeckému poznání (NRC, 1996). Mezi doporučované aktivity, které by měla badatelská výuka zahrnovat, patří především formulace výzkumných otázek a hypotéz, plánování a provádění experimentů, vyvozování závěrů a zhodnocení a prezentace získaných informací (NRC, 2012). Ačkoliv v českém školství není zařazování jednotlivých badatelských prvků do výuky př́rodopisu novinkou (Dostál, 2013), k intenzívnímu uplatňování badatelské výuky v jejím moderním pojetí dochází až v posledních letech (Ryplová \& Bezpalcová, 2016; Vácha \& Petr, 2013; Ryplová \& Reháková, 2011). Problematiku badatelsky orientovaného vyučování v prrírodních vědách v českém prostředí podrobněji rozebírá např. Papáček (2010) nebo Dostál (2013).

\section{Uplatnění interaktivní tabule v badatelsky orientovaném vyučování}

Zahraniční literatura hovoří o využívání moderních didaktických technologií, jejichž reprezentantem je i interaktivní tabule, $\mathrm{v}$ souvislosti s jejich uplatněním v badatelsky orientovaném vyučování většinou pozitivně. Vhodné využití moderních didaktických technologií včetně digitálních medií, simulací a počítačových modelů může výrazně podpořit snahy učitele o zařazování badatelských prvků do výuky a tím usnadnit a urychlit implementaci badatelsky orientované výuky (Hong et al., 2014; Lee et al., 2010; Higgins 
\& Spitulnik, 2008; Prapavessi, 2006). Napríklad využití virtuálních simulací a modelů podle van Joolingena, de Jonga \& Dimitrakopoulouta (2007) usnadňuje badatelskou výuku díky možnosti vizualizací, které nejsou v klasické terénní práci realizovatelné. Právě vizualizace jsou velmi nápomocné pro aktivity doporučované $\mathrm{v}$ rámci badatelské výuky pro podporu komunikačního aparátu, např. ve fázi získávání informací a formulace výzkumných otázek a hypotéz (NRC, 2012). Jako velmi výhodné se jeví využití moderních technologií i v takových etapách badatelské výuky, jako je sběr a analýza dat, vyvozování závěrů a vzájemná komunikace žáků nad nimi, či jejich následná prezentace (Mercer, Hennessy, \& Warwick, 2010; Kim, Hannafin \& Bryan, 2007). Podle poznatků studie Odcházelové (2015), vidí čeští učitelé význam multimediálních technologií ve výuce především ve fázi motivace, tedy aktivity, která stojí nutně i na začátku jakékoli badatelské výuky (NRC, 2012). Současní žáci základních škol jsou navíc zvyklí používat tzv. chytré technologie i v běžném životě, nebot' jako zdroj získávání informací nejčastěji používají digitální média a internet (JWT, 2012). Výuka s využitím moderních technologií bývá proto žáky ZŠ většinou přijímána s nadšením (Stárková \& Rusek, 2015; Sad \& Ozhan, 2012; Hall \& Higgins, 2005). Potenciál žáky oblíbených moderních digitálních technologií vhodně využitý $\mathrm{v}$ badatelské výuce by tedy zřejmě mohl přispět $\mathrm{k}$ zatraktivnění výuky prírodovědných předmětů a napomoci implementaci badatelského př́stupu do výuky. Interaktivní tabule se na českých základních školách staly v posledních letech široce dostupnými (např́klad díky projektům Státní informační politiky ve vzdělávání). Učitelé př́rodopisu tedy mají většinou možnost interaktivní tabule používat i v BOV. Není však známo, $v$ jak velkém rozsahu a jakým způsobem jsou interaktivní tabule českými učiteli př́rodopisu $\mathrm{v}$ BOV využívány a s jakými problémy se uplatnění IT $\mathrm{v}$ BOV v českém prostředí potýká. $\mathrm{S}$ ohledem na to byla provedena sonda, jejímž cílem bylo tyto prvotní informace přinést a zodpovědět následující výzkumné otázky:

1. V jaké míre čeští učitelé uplatňující badatelský př́stup ve výuce přírodopisu používají k BOV interaktivní tabuli?

2. Jaké jsou praktické zkušenosti učitelů, limity a šance pro použivání interaktivní tabule v BOV v prírodopisu?

Vedlejším cílem provedené sondy bylo zjistit, $\mathrm{k}$ jakým účelům učitelé prŕrodopisu interaktivní tabuli nejčastěji využívají i mimo BOV.

\section{Metodika}

Formou krátkého dotazníkového šetření byla na základních školách provedena sonda míry využivání interaktivní tabule mezi učiteli přírodopisu pro 5. - 9. ročník základních škol, kteří byli pro implementaci BOV do výuky vyškoleni na některém z odborných seminářů (např. letní školy BOV, pilotní projekt Škola BOV katedry biologie PF JU či projekt Badatelé vzdělávacího centra Tereza), v praxi BOV aktivně používají a uvedli, že zároveň využívají ve výuce i interaktivní tabuli. Podmínka odborného proškolení učitele v moderním pojetí badatelsky orientované výuky byla nutným kritériem výběru respondentů v zájmu zajištění objektivity výzkumu. Zahraniční zkušenosti totiž naznačují, že princip badatelské výuky bývá učiteli často nesprávně pochopen a zjednodušován (Crawford, 2000). Jako badatelská výuka je pak nesprávně označována např. jakákoliv praktická či projektová výuka či laboratorní práce, v nichž žáci postupují přesně podle učitelem předloženého návodu a míra vlastního „aktivního bádání“ žáka je pak minimální. Sondy se zúčastnilo celkem 55 učitelů ze 42 škol z Jihočeského, Jihomoravského 
a Středočeského regionu a regionu Vysočina. Věk respondentů byl v rozmezí 28 - 49 let. Získaná data byla statisticky vyhodnocena pomocí programu Excel. Respondenti zodpovídali tyto otázky:

1. Používáte interaktivní tabuli v badatelské výuce?

a) ANO ........... prejejěte na ot. 2 a

b) NE............. přejděte na ot. $2 b$

2.a. V čem vidíte na základě vlastní zkušenosti př́nos interaktivní tabule pro badatelskou výuku?

2.b. Pokud interaktivní tabuli v badatelské výuce nepoužíváte, uved’te, prosím důvody, proč:

3. Považujete používání interaktivní tabule v badatelské výuce za vhodné?

a) ANO

b) $\mathrm{NE}$

3. Z následujícího seznamu vyberte, jakým způsobem interaktivní tabuli při výuce př́ŕodopisu využíváte (at' už v badatelském vyučování či mimo něj, možno vybrat více možností):

a) Vytvárím vlastní interaktivní výukové materiály

b) Používám interaktivní výukové materiály jiných autorů (at' už komerčně vydávané, zpracované kolegy, z internetu apod.)

c) Použivám didaktické hry

d) K testování žáků

e) K promítání prezentací - jako dataprojektor

f) V badatelské výuce

\section{Výsledky}

Interaktivní tabuli $\mathrm{v}$ př́mo $\mathrm{v}$ badatelském vyučování využívalo pouze 6 učitelů $\mathrm{z}$ oslovených 55 . Na otázku 2a tedy odpovídalo pouze 6 učitelů, kteří IT v BOVB používají. Tito učitelé uváděli ve 4 př́padech takové výhody IT, které lze shrnout pojmem „lepší názornost“ (např. propojení závěrů pokusu s obrázky na začátku, propojení výzkumné otázky a nalezené odpovědi, možnost změny chybných závěrů apod.) ve 2 případech nadšení dětí pro výuku s využitím IT a $\mathrm{v}$ jednom př́ípadě zrychlení postupu badatelské lekce díky IT (1 učitel uvedl dvě výhody).

Na otázku $2 b$ odpovídalo 49 učitelů. Odpovědi, uváděné učiteli jako důvody k nepoužívání interaktivní tabule v BOV bylo možno po roztřídění rozdělit do 4 hlavních skupin (graf 1):

1. Rozvrhová nedostupnost učebny vybavené IT v požadované době (době, kdy probíhá badatelská výuka). Tento důvod uvedlo 24 ze 49 učitelů, kteří interaktivní tabuli v BOV nevyužívají (tj cca $49 \%$ ).

2. Časová náročnost př́ípravy (17 učitelů, tj. cca $35 \%$ ).

3. Nemožnost provádění badatelských pokusů na IT (12 učitelů, tj. cca $24 \%)$ ).).

4. Neexistence hotových materiálů pro badatelskou výuku na IT (6 učitelů, tj. cca $12 \%)$. 
Někteří učitelé uvedli více důvodů zároveň.

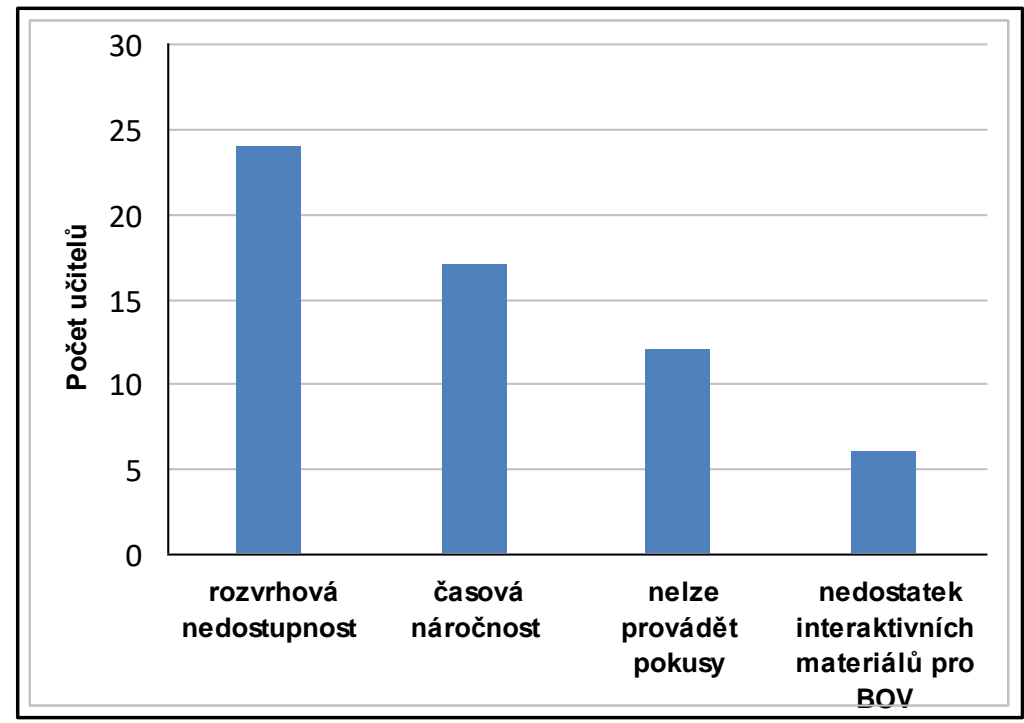

Graf 1: Důvody pro nepouživání interaktivní tabule v badatelské výuce v prírodopisu. (odpovédi na otázku č. 2: „Pokud interaktivní tabuli v badatelské výuce nepouživáte, uved'te, prosím di̊vody, proč. " $n=49$, někteři učitelé uvedli více duvodi̊ zároveñ)

Ačkoliv IT ve výuce přírodopisu aktivně používalo pouze 6 učitelů, nadpoloviční většina učitelů (36) použití interaktivní tabule v badatelské výuce za vhodné považovala. Častěji než pro badatelskou výuku byla IT využívána jen jako pouhý dataprojektor (28x), $\mathrm{k}$ testování a hodnocení znalostí žákủ (25x) či k didaktickým hrám (24x). Učitelé většinou využívali IT ve výuce více možnými způsoby. Převážná většina, (32 oslovených učitelů), využívala $\mathrm{k}$ výuce výukové materiály jiných autorů. Vlastní výukové materiály si $\mathrm{k}$ výuce vytvářelo 9 učitelů, (včetně 6 učitelů využívajících IT v BOVB), z toho 5 učitelů uvedlo, že použivají vlastní i cizí výukové materiály (graf 2). 


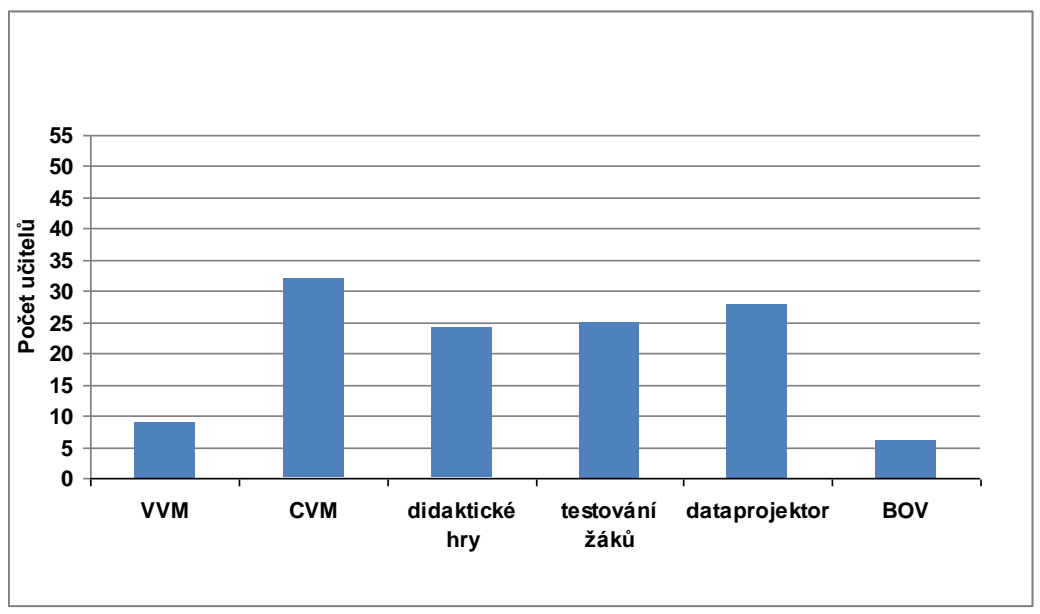

Graf 2: Způsoby využití interaktivní tabule ve výuce u učiteli̊ ZŠ aktivně uplatňujících ve výuce badatelský princip a míra využití interaktivní tabule v BOV (otázka č.4). VVM= vlastni výukové materiály (učitelé, kteři uvedli, že při výuce použivaji výukové materiály, které si sami vytvárejí). CVM= cizi výukové materiály (učitelé, kteři uvedli, že využivaji výukové materiály pro IT od jiných autorů), BOV = Badatelsky orientované vyučování (učitelé, kteři uvedli, že interaktivni tabuli použivaji v badatelsky orientovaném vyučování), $n=55$.

\section{Diskuze}

Vzhledem k tomu, že badatelská výuka se na českých školách teprve začíná uplatňovat, mohla být sonda provedena pouze na poměrně malém vzorku respondentů ( 55 učitelů). Jak již bylo uvedeno výše, bylo obtížné nalézt dostatečný počet v badatelské výuce odborně vyškolených učitelů prrírodopisu, kteří zároveň sami IT ve výuce také využívají. Výsledky sondy lze proto vzhledem k nízkému počtu respondentů považovat pouze za orientační, nicméně naznačují některá významná fakta:

Interaktivní tabuli v badatelské výuce využívalo minimum oslovených učitelů a to i přesto, že nadpoloviční většina oslovených respondentů využití interaktivní tabule v BOV v př́rodopisu za vhodné považovala.

Oněch 6 učitelů, kteří s používáním IT v BOV již mají praktické zkušenosti, považovalo ze př́nosné především zlepšení názornosti a tím podporu vyvozování souvislostí a závěrů studenty. Poznatky českých učitelů se tedy shodují i se zahraničními studiemi, které u interaktivních studií vyzdvihují právě názornost (Lee et al., 2010; Higgins \& Spitulnik, 2008; Prapavessi, 2006).

Důvody, které učitelé uváděli jako vysvětlení pro nevyužívání IT v BOV (graf 1) v odpovědích na otázku č. 2 bylo možno rozdělit do 4 oblastí:

Nejčastěji uváděným důvodem byla rozvrhová nedostupnost učebny vybavené interaktivní tabulí v době výuky. Na většině škol byla interaktivní tabule umístěna v učebně 
s běžnou celodenní výukou a pro učitele bylo rozvrhově obtížné zajistit výuku své badatelské lekce $\mathrm{v}$ požadovaný čas právě v této učebně.

Druhou oblastí zmiňovaných důvodů byla časová náročnost přípravy. Badatelsky orientované vyučování klade, jak známo, velké nároky na př́pravu učitele (NRC, 2012; Crawford, 2000), zvýšené časové nároky na př́ípravu učitele vyžaduje i vhodné využití interaktivní tabule (Flick \& Bell, 2000). Má - li učitel připravit pro badatelskou výuku navíc také aplikace pro IT, časová náročnost př́pravy přirozeně vzrůstá. Ačkoliv př́íprava interaktivní tabulí podporované badatelské výuky je pro učitele časově náročná, jak uvádí Bidaki \& Mobasheri, (2013), př́mo ve výuce mủže zajistit významnou časovou úsporu. Zrychlení průběhu badatelské lekce díky použití interaktivní tabule ocenil i jeden $\mathrm{z}$ respondentů $\mathrm{v}$ této studii. Tento fakt nabývá na významu zvláště $\mathrm{v}$ souvislosti se zjištěním studií, které sledovaly stav uplatňování BOV v př́rodopisu na českých základních školách a ukazují, že právě nedostatek času učitelů ve výuce je jednou z překážek při zavádění BOV (Vácha \& Petr, 2013).

Další skupinu důvodů pro nepoužívání IT v BOV uváděných učiteli je možno souhrnně označit jako „nemožnost provádění pokusů a tudiž nevhodnost pro BOV“. Jak naznačují zahraniční studie (Hall \& Higgins, 2005; Mercer, Hennessy \& Warwick, 2010), technický potenciál interaktivní tabule však může být v BOV s výhodou využíván ve zcela jiných a neméně významných etapách badatelské výuky, než je samotné provádění pokusů, konkrétně zejména $\mathrm{v}$ úvodní motivaci, formulaci hypotéz či např. vyvozování závěrů. Technické možnosti interaktivní tabule umožňují rychlou vizualizaci souvislostí, propojování zaznamenaných výsledků experimentů s úvodními otázkami, seskupování výsledkủ či jejich filtraci apod. (Smetana \& Bell, 2012; Lee et al., 2010; Higgins \& Spitulnik, 2008). Toto vše pak podporuje a urychluje proces samostatného vyvozování závěrů studentem, tedy jeden $\mathrm{z}$ hlavních cílů badatelského principu. Tento typ odpovědí proto vyzývá k zamyšlení, zda tito učitelé, skutečně pochopili problematiku BOV v jeho plné šíri a neopomíjejí právě stěžejní etapy BOV podporující komunikační aparát, v nichž lze interaktivní tabuli velmi výhodně využít. Ačkoliv práce $\mathrm{s}$ živými př́rodninami a praktické provádění experimentů je právě ve výuce biologie nezbytnou součástí, chápat BOV jako pouhé „provádění experimentư” je chybné. Toto zjednodušování badatelského príistupu na pouhé ,hands-on activity” vytržené $\mathrm{z}$ kontextu řešeného problému bývá i podle zahraničních zkušeností (Crawford, 2000) zcela nežádoucím efektem při zavádění badatelské výuky. V takovém př́padě pak nemůže být naplněn požadavek komplexního př́istupu k problému, který je s badatelskou výukou neodmyslitelně spjat (Bybee, 2004; Rochard et al., 2007; NRC, 2012).

Poslední oblast důvodů uváděných učiteli je možné charakterizovat jako nedostupnost hotových, připravených materiálů pro IT využitelných v BOV. Odpovědi tohoto typu byly vesměs zaznamenány u učitelů, kteří ani $\mathrm{v}$ běžné výuce nevytvářejí vlastní výukové materiály pro IT, nýbrž jsou zvyklí využívat materiály připravené jinými autory (at' už vydané pedagogickými nakladatelstvími, zpracované kolegy ze školy či získané z různých internetových portálů). Nedostupnost kvalitních výukových materiálů pro IT zpracovaných podle badatelského principu zmiňovali i vyučující, kteří IT používají pouze $\mathrm{k}$ testování žáků či promítání prezentací. Zaznamenána byla také u pedagogů, kteří uváděli jako příčinu nevyužívání IT v BOV velkou časovou náročnost př́ípravy. Tvorba materiálů pro badatelskou výuku podporovanou interaktivní tabulí vyžaduje ze strany učitele, kromě času při její př́pravě, také značnou dávku kreativity i technické schopnosti k ovládání IT. 
(Gursul \& Tozmaz, (2010); Hammond, Reynolds \& Ingram, 2011). Na základě poznatků této sondy tedy lze dojít k závěru, že větší množství dostupných, kvalitních materiálů pro IT, sestavených správně podle badatelských principů, by bylo učitelskou veřejností zřejmě pozitivně príijímáno.

Zdá se tedy, že využití IT v BOV naráží na řadu problémů a není v praxi zatím př́liš časté. Mnohem častěji než $\mathrm{k}$ badatelské výuce využívají učitelé IT ve výuce prírodopisu k testování žáků či k promítání prezentací (graf 2). Potenciál interaktivní tabule využitelný $\mathrm{s}$ výhodou $\mathrm{v}$ jednotlivých výše popsaných fázích badatelské výuky tedy zatím není plně využit. V této studii nemohl být, vzhledem $\mathrm{k}$ omezené velikosti vzorku respondentů, sledován vliv věku učitelů na míru využití IT v BOV v př́rodopisu. Nadějí do budoucna by mohli být mladší učitelé, kteří již náleží $\mathrm{k}$ tzv. generaci $\mathrm{Y}$, jsou tedy zvyklí na častější užívání interaktivních technologií. Tuto domněnku potvrzuje napřs. studie provedená mezi studenty učitelství chemie (Stárková \& Rusek, 2015) potvrzující jejich zájem o využití ICT $\mathrm{v}$ budoucí pedagogické praxi.

\section{Závěry}

1. Míru využití interaktivní tabule $\mathrm{v}$ badatelské výuce $\mathrm{v}$ př́rodopisu na českých základních školách lze zatím považovat za velmi nízkou. Výsledky sondy naznačují, že potenciál IT pro BOV zatím není v praxi dostatečně využit. Učitelé sice většinou považují interaktivní tabule za vhodné pro uplatnění v badatelské výuce, sami je však aktivně v rámci badatelské výuky používají jen zřídka.

2. Učitelé využívající IT v BOV vidí její přínos hlavně ve zlepšení názornosti vyvozovaných souvislostí.

3. Překážkami pro častější využití interaktivních tabulí v BOV se jeví rozvrhová nedostupnost učebny vybavené IT, časová náročnost učitelské přípravy na badatelskou výuku s IT a nedostatek kvalitních připravených výukových materiálů. Závažným zjištěním sondy je i naznačení problému nesprávného pochopení samotného principu badatelské výuky některými vyučujícími, kteří vidí badatelskou výuku $\mathrm{v}$ biologii zjednodušeně jako pouhé provádění praktických aktivit $\mathrm{v}$ rámci žákovských experimentů a př́ležitosti pro využití IT v BOV tedy neumí správně identifikovat.

Limitem provedené sondy byl nízký počet respondentů, její výsledky lze proto prozatím považovat pouze za orientační. Jako vhodné se do budoucna jeví provést hlubší sondu s časovým odstupem až po širším zavedení badatelského principu do výuky př́rodopisu, tedy s možností zapojení většího počtu respondentů $\mathrm{z}$ řad $\mathrm{v}$ badatelské výuce fundovaných učitelů základních škol. Zapojení většího množství respondentů pak umožní rozsáhlejší analýzy této problematiky.

Poděkování:

Př́spěvek vznikl za podpory projektu GAJU 118/2016/S. 


\section{Literatura}

Bell, R.L., Smetana R.K., Binns, I.C. (2005). Symplifying inquiry instruction: assesing the inquiry level of classroom activities. Sci Teach 72(7). pp. $30-33$.

Bybee, R.V. (2004). Scientific inquiry and science teaching, In L.B. Flick \& G.Lederman, (Eds.), Science inquiry and nature of science. Implications for teaching, learning, and teacher education $(1-14)$. Dordrecht: Kluwer Academic Publisher.

Bidaki, M. Z. \& Mobasheri, N. (2013). Teachers' Views of the Effects of Interactive White Board (IWB) on Teaching. In H. Uzunboylu \& F. Ozdamli, ( Eds), 2nd World Conference of Educational Technology Research (WCETR). Nicosia, Cyprus. Procedia Social and Behavioral Sciences 83. pp. 140 - 144.

Crawford, B.A. (2000). Embracing the Essence of Inquiry: New Roles for Science Teachers. Journal of Research in Science Teaching, 37(9). pp. 916-937.

Dostál, J. (2013). Badatelsky orientovaná výuka jako trend soudobého vzdělávání. $e$ Pedagogium 2013(3). pp. 81 - 94.

Flick, L. \& Bell, R. (2000). Preparing tomorrow's science teachers to use technology: guidelines for Science educators. Contemp Issues Technol Teach Educ 1. pp. 39-60.

Gursul, F. \&Tozmaz, G. B. (2010). Which one is smarter? Teacher or board. Procedia Social and Behavioral Sciences 2, pp. 5731-5737.

Hall, I. \& Higgins, S. (2005). Primary school students' perceptions of interactive whiteboards. Journal of Computer Assisted Learning, 21. pp. 102-117.

Hammond, M., Reynolds, L. \& Ingram, J. (2011). How and why do students teachers use ICT. Journal of Computer assisted learning 27(3). pp. $191-203$.

Higgins, T.E. \& Spitulnik, M.W. (2008). Supporting teachers' use of technology in science instruction through professional development: a literature review. J Sci Educ Technol 17. pp. 511-521.

Hong, J.Ch., Hwang, M.Y., Liu, M.Ch, Ho,H.Y. \& Chen, Y.L.(2014). Using a "predictionobservation-explanation" inquiry model to enhance student interest and intention to continue science learning predicted by their Internet cognitive failure. Computers \& Education, 72. pp.110-120

JWT, (2012). Gen Z: Digital in their DNA. Dostupné z http://www.jwtintelligence.com/wpcontent/uploads/2012/04/F_INTERNAL_Gen_Z_0418122.pdf

Kim, M. C., Hannafin, M. J. \& Bryan, L.A. (2007). Technology-enhanced inquiry tools in science education: An emerging pedagogical framework for classroom practice. Science Education 91(6). pp. $1010-1030$.

Lee H., Linn, M.C., Varma, K. \& Liu, O.L. (2010). How do technology enhanced inquiry science units impact classroom learning? J Res Sci Teach 47. pp. 71-90.

Mercer, N., Hennessy, S., \& Warwick, P. (2010). Using interactive whiteboards to orchestrate classroom dialogue. Technology, Pedagogy and Education, 19(2). pp. 195209.

National Research Council (NRC), (1996). National Science Education Standards; National Academies Press: Washington, DC.

National Research Council (NRC).(2012). A Framework for K-12 Science Education: Practices, Crosscutting Concepts, and Core Ideas. Washington, DC: The National Academies Press, dostupné z : http://www.nap.edu/catalog.php?record_id=13165\# 
Odcházelová, T. (2015). Beliefs of the biology teachers about using multimedia. Problems of Education in the 21 st Century, 63, 71-83.

Papáček, M. (2010). Badatelsky orientované prŕrodovědné vzdělávání - cesta pro vzdělávání generací Y, Z a alfa? Scientia in Educatione, 1(1), pp. 33-49. Dostupné z http://www.scied.cz

Prapavessi, D. (2006). Work in progress: Wireless tablet technology in the calculus classroom leads to inquiry and discovery. Proceedings-Frontiers in Education Conference, San Diego. pp.1683 - 1684.

Rochard, M. Csermely, Jorde, D. Lenzen, D. Walberg-Henrikson, H. \& Hermmo, U. (2007). Science education now: A renewed pedagogy for the future of Europe. European Commission, Directorate- General for Research, Science, Economy and Society, Information and Communication Unit, Brussels. Dostupné z: http://ec.europa.eu/research/science-society/document_library/pdf_06/report-rocard-onscience-education_en.pdf

Ryplová R. \& Bezpalcová E. (2016). An impact of guided inquiry on students understanding of plant water metabolism - a case study. 9th annual International Conference of Education, Research and Innovation, (ICERI), 14-16 November, 2016, Seville, Spain, pp. 7533-7538, Dostupné z : 10.21125/iceri.2016.0717

Ryplová, R. \& Reháková, J. (2011) : Přínos badatelsky orientovaného vyučování (BOV) pro environmentální výchovu: Př́ípadová studie implementace BOV do výuky na ZŠ. Envigogika 2011/VI/3 dostupné http://www.envigogika.cuni.cz/index.php/cz/recenzovane-clanky/2011/envigogika2011 vi3/606-prinos-badatelsky-orientovaneho-vyucovani-bov-pro-environmentalnivychovu-pripadova-studie-implementace-bov-do-vyukyna-zs

Sad, S.N. \& Ozhan, U. (2012). Honeymoon with IWBs: A qualitative insight in primary students' views on instruction with interactive whiteboard. Computers \& Education, 59(4). pp. 1184-1191.

Smetana, L. K. \& Bell R. (2012). Computer Simulations to Support Science Instruction and Learning: A critical review of the literature. International Journal of Science Education 34(9). pp.1337 - 1370.

Stárková, D. \& Rusek, M. (2015). Postoje studentů učitelství chemie k využití informačních a komunikačních technologií ve výuce chemie. In H. Cídlová (Ed.), XXIV. Mezinárodni konference o výuce chemie Didaktika chemie a její kontexty, Brno (s. 193199).Masarykova univerzita.

Dostupné z: https://munispace.muni.cz/index.php/munispace/catalog/download/780/2498/408-1 Vácha, Z. \& Petr J. (2013). Inquiry based education at primary school throught school gardens. Journal of International Scientific Publications: Education Alternatives 11(2). pp. $219-230$.

Van Joolingen, W.R. de Jong, T. \& Dimitrakopoulout, A. (2007). Issues in computer supported inquiry learning in science. J Comput Assist Learn 23. pp. 11-119. 